\title{
DYSFUNCTIONAL CUSTOMER BEHAVIOR - A REVIEW OF RESEARCH FINDINGS
}

\author{
Krzysztof Błoński ${ }^{\bowtie}$ \\ University of Szczecin, Poland
}

\begin{abstract}
Market changes in consumer behavior can take a desirable, positive form and be accepted by other market participants, or they can be contrary to accepted social norms. According to Fullerton and Punj [1998] such behavior is the great paradox of modern consumer culture. Dysfunctional consumer behavior has become an inherent part of modern consumer behavior. The purpose of this paper is to review the results of research on dysfunctional consumer behavior based on selected scientific publications. The presentation of research topics and results will be made in two separate parts. The first part concerns the dysfunctional behaviors of customers, i.e. the way they are presented in the literature and the factors determining such behavior. The second part includes a review of research results concerning the broadly understood consequences of dysfunctional customer behavior.
\end{abstract}

Key words: customer behavior, dysfunctional customer behavior, research review

JEL codes: D11, D12

\section{INTRODUCTION}

Market transformations occur not only under the influence of changes in the environment, i.e. among the entities and objects that form a certain market, but also under the influence of passing time. It causes evolutionary or revolutionary changes in customer behavior. Such changes may assume a desirable, positive form and be accepted by other market participants. This is exemplified by the presentations in the relevant literature of factors influencing such changes [Mothersbaugh and Hawkins 2016, Solomon 2018].

The market also reveals changes that are contrary to accepted social norms, which are the result not only of changes taking place in the market but also of individual characteristics of customers. These may include: stealing, lying, forging documents, vulgar or aggressive behavior towards sellers or other customers, or alcohol or drug abuse. These are in the vast minority in comparison to positive changes, which does not mean that they escape researchers dealing with consumer behavior.

According to Fullerton and Punj [1998], consumer misbehavior is the great paradox of contemporary consumer culture - its positive features trigger its negative ones. Consumer misbehavior has become an inherent part of modern consumer behavior and is sustained by the same factors that define the essence of consumer culture. That is, consumer misbehavior is the result of the inadvertent stimulation of consumption ideology 
by the marketing activities of companies [Fullerton and Punj 2004].

The purpose of this article is to review research findings on dysfunctional customer behavior based on selected academic publications ${ }^{1}$. The presentation of the research results will be made in two separate parts. The first part will concern the dysfunctional behaviors of customers, i.e. the way they are described in the relevant literature and the factors that determine such behavior. The second part will include a review of research results concerning the broadly understood consequences of dysfunctional customer behavior.

\section{DYSFUNCTIONAL CUSTOMER BEHAVIOR - DEFINITION, FACTORS SHAPING THEIR BEHAVIOR}

Disapproved customer behavior does not have a single name in the literature, it is referred to as: jaycustomers, problematic customers, dishonest customers, bad customers, abnormal consumer behavior, bad consumer behavior, deviant consumer behavior, opportunistic consumer behavior, unethical consumer behavior, dysfunctional customer behavior, consumer retaliation, verbal aggression by customers, customers from hell or pathological consumer behavior [Smyczek et al. 2017]. A review of definitions reveals that authors address different aspects of such behaviors and use ethical, pathological, or deviant issues in their definitions (Table 1). The cited definitions indicate that there are no fundamental differences between the perception of such behaviors; the proposed nomenclature can be treated as similar, complementary. For the purposes of this article the author has adopted the phrase of 'dysfunctional customer behavior' as a neutral term in comparison with others mentioned above [Harris and Reynolds 2003].

Fisk and others [2010], based on previous research findings, distinguished various categories of such behaviors. In addition to the aforementioned stealing, vandalism and verbal abuse they indicate that such actions may have different motives (financial and non- financial), they may be impulsive or planned, with different frequency, as well as having overt or covert nature [Fisk et al. 2010, p. 420].

Consumer behavior in the literature is generally analyzed in the context of factors that influence such behavior in the market. Also in this case of dysfunctional behaviors one can point to theoretical and research achievements. Examples of publications that deal with this subject can be [Fisk et al. 2010, Smyczek et al. 2017].

Looking at the general pattern of consumer behavior, the basis of every action is a motive. In the case of dysfunctional behavior, the motive may be financial, one's own ego gratification, or a revenge motive [Daunt and Harris 2012]. On this basis, three types of dysfunctional behaviors were identified that differ in terms of behavioral motives. These are:

1. Financial egotists - in this case financial and selfish issues are the motive for the dysfunctional behavior.

2. Money grabbers - motivated purely by financial concerns

3. Ego revengers - the motivation for misbehavior is revenge and ego issues.

Examples of other surveys addressing the issue of motives for clients' dysfunctional behaviors include among others [Harris and Reynolds 2004].

It should be noted that research on the causes of dysfunctional customer behavior is not limited to the issue of motives. An example of research that verifies models that may explain dysfunctional behavior is presented, for example, in the work of Reynolds and Harris [2009]. Other authors analyze the importance of only certain groups of factors or single variables. These may include institutional and socio-cultural factors [Agnihotri and Bhattacharya 2019], the importance of place of birth (city or village) [Zhao and Xu 2013] or impulse buying [Bossuyt et al., 2017]. Another notable line of research is the creation of typologies of dysfunctional consumers. Examples of such research are the works of [Zemke and Anderson 1990, Fullerton and Punj 2004, Harris and Reynolds 2004, Dogan et al. 2017, Smyczek et al. 2017].

\footnotetext{
${ }^{1}$ This article is part of a broader research project in which members of the research team, to which the author belongs, set themselves the goal of examining dysfunctional human behavior as a consumer and employee.
} 
Błoński, K. (2020). Dysfunctional customer behavior - a review of research findings. Acta Sci. Pol. Oeconomia 20 (2), 5-12, doi: 10.22630/ASPE.2021.20.2.10

Table 1. Selected definitions of inappropriate customer behavior in the relevant literature

\begin{tabular}{|c|c|c|}
\hline Author & $\begin{array}{l}\text { Term } \\
\text { in English }\end{array}$ & Definition, description \\
\hline $\begin{array}{l}\text { Lovelock Ch. } \\
\text { and Wirtz J. [2011] }\end{array}$ & jaycustomers & $\begin{array}{l}\text { A customer acting in a thoughtless or inappropriate manner, causing problems for both } \\
\text { companies, staff and other customers. }\end{array}$ \\
\hline $\begin{array}{l}\text { Fullerton R.A. } \\
\text { and Punj G. [1993] }\end{array}$ & $\begin{array}{l}\text { aberrant } \\
\text { consumer } \\
\text { behavior }\end{array}$ & $\begin{array}{l}\text { These are behaviors that violate generally accepted norms of conduct in the market, con- } \\
\text { sidered unacceptable by sellers and most consumers. The consequences of such behavior } \\
\text { include: destruction of seller's property; intimidation, physical and psychological victimi- } \\
\text { zation of other consumers and staff; material loss as a result of various types of sales. }\end{array}$ \\
\hline $\begin{array}{l}\text { Fullerton R.A. } \\
\text { and Punj G. [2004] }\end{array}$ & $\begin{array}{l}\text { consumer } \\
\text { misbehavior }\end{array}$ & $\begin{array}{l}\text { Behaviors that violate generally accepted norms of behavior in the consumption sphere } \\
\text { and thus disrupt the order of consumption. Bad behavior is part of people's role as consu- } \\
\text { mers in the market. }\end{array}$ \\
\hline $\begin{array}{l}\text { Moschis G.P. } \\
\text { and Cox D. [1989] }\end{array}$ & $\begin{array}{l}\text { deviant } \\
\text { consumer } \\
\text { behavior }\end{array}$ & $\begin{array}{l}\text { Behavior that deviates from commonly accepted norms, standards. Standards and norms } \\
\text { take the form of customs, rules, regulations, laws. }\end{array}$ \\
\hline $\begin{array}{l}\text { Hayes-Roth B. } \\
{[1982]}\end{array}$ & $\begin{array}{l}\text { opportunistic } \\
\text { consumer } \\
\text { behavior }\end{array}$ & $\begin{array}{l}\text { Opportunism can be defined as the insidious pursuit of maximizing consumer benefits, } \\
\text { which includes lying, stealing, or cheating. } \\
\text { The problems people face, such as where to shop and what to buy, are based on an } \\
\text { opportunistic approach. This means that what may seem like random disorder is actually } \\
\text { a common consumer behavior. }\end{array}$ \\
\hline $\begin{array}{l}\text { Mitchell V.W. } \\
\text { Balabanis G., } \\
\text { Schlegelmilch B.B. } \\
\text { and Cornwell T.B. } \\
\text { [2009] }\end{array}$ & $\begin{array}{l}\text { unethical } \\
\text { consumer } \\
\text { behavior }\end{array}$ & $\begin{array}{l}\text { Direct or indirect actions that cause businesses or other consumers to lose money } \\
\text { or reputation. }\end{array}$ \\
\hline $\begin{array}{l}\text { Reynolds K.L. and } \\
\text { Harris L.C. [2009] }\end{array}$ & $\begin{array}{l}\text { customer } \\
\text { dysfunctional } \\
\text { behavior }\end{array}$ & $\begin{array}{l}\text { These are situations where the consumer knowingly violates commonly accepted norms } \\
\text { of behavior in the sphere of consumption. The use of the term dysfunctional behavior is } \\
\text { intended to emphasize the issue of intent and violation of norms. }\end{array}$ \\
\hline $\begin{array}{l}\text { Smyczek S., Grybś } \\
\text { - Kabocik M., } \\
\text { Matysiewicz J., } \\
\text { Tetla A. } \\
\text { [2017] }\end{array}$ & $\begin{array}{l}\text { pathological } \\
\text { consumer } \\
\text { behavior }\end{array}$ & $\begin{array}{l}\text { Behaviors that are contrary to generally accepted norms of behavior in the context } \\
\text { of consumption, having a negative impact both on the consumers who conduct such } \\
\text { behavior, other consumers, employees, and the company. }\end{array}$ \\
\hline
\end{tabular}

Source: Author's own compilation based on [Smyczek et al., 2017, p. 48-55].

\section{A REVIEW OF RESEARCH RESULTS ON THE CONSEQUENCES OF DYSFUNCTIONAL CUSTOMER BEHAVIOR}

Another area of research on dysfunctional customer behavior is the consequences of the behavior of such customers. Consequences refer not only to the financial losses incurred by firms, but also to the consequences incurred by employees who come into direct contact with such customers. In a study by Harris and Reynolds [2003] in relation to a group of employees, four sets of such consequences are distinguished:
1. Long-term psychological - the result of employees being exposed to prolonged dysfunctional customer behavior. They are juxtaposed with the term "long-term" to indicate a situation where the consequences last much longer than the occurrence of the particular dysfunctional client behavior. Consequences included in this group take two forms: persistent feelings of degradation and disorders resulting from stress.

2. Short-term emotional - affect employees for a shorter period of time than those in the previous group. 
They manifest themselves in the form of a negative impact on the mood or temperament of employees or the need to pretend to show emotions, usually in order to calm disruptive customers.

3. Behavioral - manifested in the form of lowered employee morale and reduced levels of motivation. In situations where dysfunctional behaviors are sporadic and non-invasive, a positive impact on employee team performance can be observed. In these cases, team leaders may reveal themselves and team members may offer compassion and support. Among their reactions, employees may also move toward revenge, retaliation (but these are most likely to be actions designed to allow them to unwind previous dysfunctional behaviors), or sabotaging the efforts of dysfunctional clients.

4. Physical effects - focuses on the physical impact on employees who come in contact with dysfunctional customers. They refer to tangible injuries or damage to employees and/or their property. Therefore, two forms can be identified in this group: violence against the employee and damage to employees' personal property.

To review the research findings related to the consequences of dysfunctional behavior, the classification of consumer misbehavior presented in the work by Fullerton and Punj [2004] can be used as a reference for presenting the research findings of other authors. Fullerton and Punj [2004] proposed five basic categories of consumer misbehavior:

1. Consumer misbehavior directed against a marketer's employees.

2. Consumer misbehavior directed against other consumers in the exchange setting.

3. Consumer misbehavior directed against a marketer's merchandise and services.

4. Consumer misbehavior directed against a marketer's financial assets.

5. Consumer misbehavior directed against a marketer's physical or electronic premises.

The first category - consumer misbehavior directed against a marketer's employees - is characterized by an overt, verbal or physical attack on an employee of a specific company. The premise of such consumer behavior is rebellion or intimidation in order to exert a specific influence on an employee of a company as well as satisfaction resulting from the attack itself. In the case of dysfunctional customer behavior directed at company employees, we are primarily dealing with employee stress. This is evidenced by research [Dormann and Zapf 2004] indicating that there is a relationship between dysfunctional customer behavior and employee dissatisfaction and stress. On the other hand, frequent experience of dysfunctional behaviors increases stress levels as a result of trying to control their negative reactions [Grandey et al. 2007]. Completing the picture may be research findings [Yue et al. 2017] suggesting that employees' exposure to dysfunctional behavior harms them by increasing stress levels and impairing organizational performance. On the other hand, some researchers [Chi et al. 2018] note that dysfunctional behavior causes stressful situations for employees, whose most common response to such situations is to leave the company. This is supported by several studies [Babakus et al., 2010]. The possibility of preventing such employee departure is indicated by research findings from Gong and Wang [2019]. Examples of other research findings in which the theme of interaction between dysfunctional customers and the employees serving them is addressed include: Isin et al. [2010], Fong et al. [2017], Karatepe et al. [2009], $\mathrm{Li}$ and Zhou [2013], Rafaeli et al. [2012], Tan et al. [2020], Tsang et al. [2011], Yagil [2008].

The second set of research findings analyzed can be described as consumer misbehavior directed against other consumers in the exchange setting. In this case, we are also dealing with an overt verbal or physical attack, but directed at another consumer participating in the same transaction. The attacker in this situation shows dislike for the other consumer, which for the former is often a source of pleasure. The purpose of such consumer behavior is mainly to attract the attention of others.

One of the themes addressed in research in this area is the issue of how dysfunctional behavior affects other customers. The literature offers the view that the more consumers observe other consumers engaging in unethical behavior, the more likely they are to act in the same or similar ways [Albers-Miller 1999a, Reynolds and Harris 2005, Wu and Chen 2013, Liu et al. 2015, Yang et al. 2015]. According to Harris and Reynolds [2003], some customers may imitate observed 
unethical behavior while others do not engage in such unethical behavior. Whereas Yang et al. [2017] found that consumers are more likely to imitate the dysfunctional behavior of others when the behavior is performed by a like-minded person. Research findings from this area can also be found in [He et al. 2019].

The third set of research findings on the broad consequences of dysfunctional customer behavior can be called "consumer misbehavior directed against a marketer's merchandise and services". Such behavior is externalized by committing theft, the form of which may vary from violent assaults to the use of new technologies for this purpose. The emergence of such situations is often a consequence of open and easy access to goods and services offered by individuals.

In this area, shoplifting has been a frequent research subject [Kallis et al. 1986, Cox et al. 1990, Cox et. al. 1993, Phillips et al. 2005]. Due to the development of computer technology and the Internet, the attention of researchers has also been directed to the issues of digital piracy and "softlifting"3 [Tong and Yap 1998, Tan 2002, Moore and Chang 2006, Chen and Huang 2016]. It is also important to note that this theme in the research is expanding toward identifying the importance of mobile and virtual technologies for consumer misbehavior [Zolfagharian and Yazdanparast 2017].

This does not mean that all research interest has shifted to the online world. Research continues to be conducted, for example, on the reasons for purchasing contraband products [Albers-Miller 1999b] or the reasons for purchasing counterfeit luxury products [Wilcox et al. 2009].

Actions in the case of "consumer misbehavior directed against a marketer's financial assets" involve the acquisition of a company's financial assets through criminal means. Consumers engaging in such actions, in order to defraud often use the policies, strategies or tools put in place by the business to facilitate the customer's acquisition of goods or services. Examples of such behavior may include embezzlement, false claims for store accidents, credit card and lending fraud, spreading negative rumors, or product sabotage, among others. In the Polish literature, the description of the phenomenon of unauthorized payment card transactions, but from the perspective of the banking sector is presented, among others, in the paper [Staszczyk 2015], while in the article [Kurzeja and Zakonnik 2014] the authors presented the techniques of fraud in e-commerce on the Internet using anonymizing networks.

The final set of findings is "consumer misbehavior directed against a marketer's physical or electronic premises". These are actions (e.g., vandalism) taken against company-owned property or actions (e.g., hacking) taken in e-commerce. The main motive for such actions is the desire to seek strong impressions or the need to validate one's skills. In this set according to Fullerton and Punj [2004] examples of research findings include the work of [Lévy-Leboyer 1984, Hagan et al. 1985].

\section{RECAPITULATION}

As indicated in the introduction, dysfunctional behavior is an inherent component of contemporary consumer behavior. The presented examples of works on dysfunctional customer behavior are a fragment of a larger whole. However, they allow us to get an idea of the direction of research being carried out and the state of knowledge about dysfunctional customer behavior. From the theoretical and practical point of view, a significant direction of research is the relationship between employees and consumers under dysfunctional behavior. One of the overlooked directions of research is to analyze dysfunctional human behavior as a consumer and employee. According to the author of this article, it can be assumed that there is a relationship between dysfunctional human behavior as a consumer and an employee and one of these areas can determine the existence of the other. This approach will be the subject of further research.

\footnotetext{
${ }^{2}$ Softlifting is a common type of software piracy in which a legally licensed software program is installed or copied in violation of its licensing agreement. Unlike commercial piracy, the purpose of softlifting is to provide the program to multiple users rather than to sell copies for profit. Softlifting is also known as end user piracy or softloading. The most common examples of softlifting are: Providing software to more corporate users than are covered by the license agreement; Installing software licensed to an organization on home-based computers; Sharing software among friends.
} 


\section{REFERENCES}

Agnihotri, A., Bhattacharya, S. (2019). Unethical consumer behavior: the role of institutional and socio-cultural factors. Journal of Consumer Marketing 36(1), 124-135, https://doi.org/10.1108/JCM-02-2017-2093

Albers-Miller, N.D. (1999a). Consumer misbehavior: Why people buy illicit goods. Journal of Consumer Marketing 16(3), 273-287, https://doi.org/10.1108/073637699 10271504

Albers-Miller, N.D. (1999b). Consumer misbehavior: Why people buy illicit goods. Journal of Consumer Marketing 16(3), 273-287, https://doi.org/10.1108/073637699 10271504

Babakus, E., Yavas, U., Ashill, N.J. (2010). Service worker burnout and turnover intentions: roles of person-job fit, servant leadership, and customer orientation. Services Marketing Quarterly 32(1), 17-31.

Bossuyt, S., Vermeir, I., Slabbinck, H., De Bock, T., Van Kenhove, P. (2017). The compelling urge to misbehave: Do impulse purchases instigate unethical consumer behavior? Journal of Economic Psychology 58, 60-76, https://doi.org/10.1016/j.joep.2016.12.002

Chen, Y.M., Huang, T.L. (2016). Do the warning notices decrease or increase opportunistic behavior in cinemas? Journal of Retailing and Consumer Services 32, 227233, https://doi.org/10.1016/j.jretconser.2016.06.017

Chi, N.-W., Yang, J., Lin, C.-Y. (2018). Service workers' chain reactions to daily customer mistreatment: behavioral linkages, mechanisms, and boundary conditions. Journal of Occupational and Organizational Psychology 23(1), 58-70.

Cox, A.D., D. Cox, Anderson, R.D., Moschis, G.P. (1993). Social Influences on Adolescent Shoplifting Theory, Evidence and Implications for the Retail Industry. Journal of Retailing 69(2), 234-246.

Cox, D., Cox, A.D., Moschis, G.P. (1990). When Consumer Behavior Goes Bad: An Investigation of Adolescent Shoplifting. Journal of Consumer Research 17(2), 149 159, https://doi.org/10.1086/208545

Daunt, K.L., Harris, L.C. (2012). Motives of dysfunctional customer behavior: An empirical study. Journal of Services Marketing 26(4), 293-308, https://doi.org/10.1108/0 8876041211237587

Dogan, G.J., Cai, R., Anaya, J., (2017). Developing a typology of disruptive customer behaviour. International Journal of Contemporary Hospitality Management, https:// doi.org/https://doi.org/10.1108/IJCHM-08-2016-0454

Dormann, C., Zapf, D. (2004). Customer-related social stressors and burnout. Journal of Occupational Health Psychology 9(1), 61-82.
Fisk, R.P., Grove, S., Harris, L.C., Greer, D.A., Russell-Bennett, R., Wirtz, J. (2010). Customers behaving badly: A state of the art review, research agenda and implications for practitioners. Journal of Services Marketing 24(6), 417-429, https://doi.org/10.1108/08876041011072537

Fong, L.H.N., So, A.S.I., Law, R. (2017). Exploring jaycustomer behavior and handling approach in casinos. International Journal of Contemporary Hospitality Management 29(5), 1403-1425, https://doi.org/10.1108/ IJCHM-12-2015-0691

Fullerton, R.A., Punj, G. (1993). Choosing to Misbehave: a Structural Model of Aberrant Consumer Behavior. Advances in Consumer Research 20(1), 570-574, https:// www.acrwebsite.org/volumes/7515/volumes/v20/NA-20

Fullerton, R.A., Punj, G. (2004). Repercussions of promoting an ideology of consumption: Consumer misbehavior. Journal of Business Research 57(11), 1239-1249, https://doi.org/10.1016/S0148-2963(02)00455-1

Fullerton, R.A., Punj, G. (1998). The unintended consequences of the culture of consumption: An historical-theoretical analysis of consumer misbehavior. Consumption Markets \& Culture 1(4), 393-423, https://doi.org/10.108 0/10253866.1998.9670308

Gong, T., Wang, C.Y. (2019). How does dysfunctional customer behavior affect employee turnover. Journal of Service Theory and Practice 29(3), 329-352, https://doi. org/10.1108/JSTP-04-2018-0081

Grandey, A.A., Kern, J.H., Frone, M.R. (2007). Verbal abuse from outsiders versus insiders: comparing frequency, impact on emotional exhaustion, and the role of emotional labor. Journal of Occupational Health Psychology 12(1), 63-79.

Hagan, J., Gillis, A.R., Simpson, J. (1985). The class structure of gender and delinquency: Toward a power-control theory of common delinquent behavior. American Journal of Sociology 90(6), 1151-1178.

Harris, L.C., Reynolds, K.L. (2003). The Consequences of Dysfunctional Customer Behavior. Journal of Service Research 6(2), 144-161. https://doi.org/10.1177/10946 70503257044

Harris, L.C., Reynolds, K.L. (2004). Jaycustomer behavior: An exploration of types and motives in the hospitality industry. Journal of Services Marketing 18(5), 339-357, https://doi.org/10.1108/08876040410548276

Hayes-Roth, B. (1982). Opportunism in consumer behavior. Advances in Consumer Research 9(1), 132-135. Retrieved from https://www.acrwebsite.org/volumes/5914 [accessed 05.07.2021].

He, Y., Zhang, J., Zhou, Y., Yang, Z. (2019). Monkey See, Monkey Do?: The Effect of Construal Level on Consumers' Reactions to Others' Unethical Behavior. 
Journal of Business Ethics 156(2), 455-472, https://doi. org/10.1007/s10551-018-3870-x

Isin, B.F., Altintas, H., Altintas, F.C. (2010). Research on the attitudes of consumers and workers towards customer misbehaviors. Journal of Service Science 2(1), 55-80, https://doi.org/10.1007/s12927-010-0003-1

Kallis, M.J., Krentler, K.A., Vanier, D.J. (1986). The value of user image in quelling aberrant consumer behavior. Journal of the Academy of Marketing Science 14(1), 29-35. https://doi.org/10.1007/BF02722110

Karatepe, O.M., Yorganci, I., Haktanir, M. (2009). Outcomes of customer verbal aggression among hotel employees. International Journal of Contemporary Hospitality Management 21(6), 713-733, https://doi.org/10.1108/0 9596110910975972

Kurzeja, M., Zakonnik, Ł. (2014). Techniki dokonywania oszustw w handlu elektronicznym w Internecie z wykorzystaniem sieci anonimizujących [Fraud Techniques in e-commerce in the Internet with Using Anonymizing Networks]. Studia i Materiały Polskiego Stowarzyszenia Zarządzania Wiedzą 71, 92-103.

Lévy-Leboyer, C. (Ed.) (1984). Vandalism: Behaviour and motivations. Elsevier Science Publishers B.V., Amsterdam.

Li, X., Zhou, E. (2013). Influence of customer verbal aggression on employee turnover intention. Management Decision 51(4), 890-912, https://doi.org/10.1108/00251 741311326635

Liu, Z., Yang, Z., Zeng, F., Waller, D. (2015). The Developmental Process of Unethical Consumer Behavior: An Investigation Grounded in China. Journal of Business Ethics 128(2), 411-432, https://doi.org/10.1007/s10551014-2061-7

Lovelock, C., Wirtz, J. (2011). Services marketing: People, technology, strategy. Pearson, Boston.

Mitchell, V.W., Balabanis, G., Schlegelmilch, B.B., Cornwell, T.B. (2009). Measuring unethical consumer behavior across four countries. Journal of Business Ethics 88(2), 395-412, https://doi.org/10.1007/s10551-0089971-1

Moore, T.T., Chang, J.C. (2006). Ethical Decision Making in Software Piracy: Initial Development and Test of a FourComponent Model. MIS Quarterly 30(1), 167-180.

Moschis, G.P., Cox, D. (1989). Deviant Consumer Behavior. Advances in Consumer Research 16(1), 732-737. Retrieved from https://www.acrwebsite.org/volumes/5942 [accessed 05.07.2021].

Mothersbaugh, D.L., Hawkins, D.I. (2016). Consumer behavior: building marketing strategy (thirteenth). McGrawHill Education, New York.
Phillips, S., Alexander, A., Shaw, G. (2005). Consumer misbehavior: The rise of self-service grocery retailing and shoplifting in the United Kingdom c. 1950-1970. Journal of Macromarketing 25(1), 66-75, https://doi. org/10.1177/0276146705275715

Rafaeli, A., Erez, A., Ravid, S., Derfler-Rozin, R., Treister, D. E., Scheyer, R. (2012). When customers exhibit verbal aggression, employees pay cognitive costs. Journal of Applied Psychology 97(5), 931-950, https://doi. org/10.1037/a0028559

Reynolds, K.L., Harris, L.C. (2005). When service failure is not service failure: An exploration of the forms and motives of "illegitimate" customer complaining. Journal of Services Marketing 19(5), 321-335.

Reynolds, K.L., Harris, L.C. (2009). Dysfunctional Customer Behavior Severity: An Empirical Examination. Journal of Retailing 85(3), 321-335, https://doi.org/10.1016/ j.jretai.2009.05.005

Smyczek, S., Grybś-Kabocik, M., Matysiewicz, J., Tetla, A. (2017). Patalogie w zachowaniach konsumentów na rynku. Placet, Warszawa.

Solomon, M.R. (2018). Consumer Behavior Buying, Having, and Being. Pearson Education Limited, Harlow.

Staszczyk, M. (2015). Nieuprawnione transakcje bankowe jako przejaw cyberprzestępczości. Finanse i Prawo Finansowe 2(1), 43-56, https://doi.org/https://doi. org/10.18778/2391-6478.2.1.05

Tan, A.J.M., Loi, R., Lam, L. W., Chow, C.W.C. (2020). Buffering negative impacts of jaycustomer behavior on service employees. Journal of Services Marketing 34(5), 635-650, https://doi.org/10.1108/JSM-03-2019-0112

Tan, B. (2002). Understanding Consumer Ethical Decision Making with Respect to Purchase of Pirated Software. The Journal of Consumer Marketing 19(2/3), 96-111.

Tong, J., Yap, C. (1998). Testing an Ethical Decision- Marking Theory: The Case of Softlifting. Journal of Management Information Systems 15(1), 213-237.

Tsang, N.K.F., Lee, L.Y.S., Chan, P.K.Y. (2011). Staff perceptions of jaycustomers in Hong Kong bars and nightclubs. Journal of China Tourism Research 7(3), 326-342, https://doi.org/10.1080/19388160.2011.599254

Wilcox, K., Kim, H.M., Sen, S. (2009). Why Do Consumers Buy Counterfeit Luxury Brands? Journal of Marketing Research 46(2), 247-259, https://doi.org/https://doi. org/10.1509/jmkr.46.2.247

Wu, Y., Chen, V.H.H. (2013). A social-cognitive approach to online game cheating. Computers in Human Behavior 29(6), 2557-2567.

Yagil, D. (2008). When the customer is wrong: A review of research on aggression and sexual harassment in servi- 
ce encounters. Aggression and Violent Behavior 13(2), 141-152, https://doi.org/10.1016/j.avb.2008.03.002

Yang, L., Vitell, S., Bush, V.D. (2017). Unethically keeping the change while demeaning the act. Journal of Consumer Marketing 34(1), 11-19.

Yang, Z., Wang, J., Mourali, M. (2015). Effect of peer influence on unauthorized music downloading and sharing: The moderating role of self-construal. Journal of Business Research 68(3), 516-525.

Yue, Y., Wang, K.L., Groth, M. (2017). Feeling bad and doing good: the effect of customer mistreatment on service employee's daily display of helping behaviors. Personnel Psychology 70(4), 769-808.
Zemke, R., Anderson, K. (1990). Customers from Hell. Training 27(2), 25-33.

Zhao, B.C., Xu, S.S. (2013). Does Consumer Unethical Behavior Relate to Birthplace? Evidence from China. Journal of Business Ethics 113(3), 475-488, https://doi. org/10.1007/s10551-012-1317-3

Zolfagharian, M., Yazdanparast, A. (2017). The dark side of consumer life in the age of virtual and mobile technology. Journal of Marketing Management 33(15-16), 1304-1335, https://doi.org/10.1080/ 0267257X.2017.1369143

\section{DYSFUNKCYJNE ZACHOWANIA KLIENTÓW - PRZEGLĄD WYNIKÓW BADAŃ}

\section{STRESZCZENIE}

Zmiany zachodzące na rynku w zachowaniach konsumentów mogą przybierać postać pożądaną, pozytywną i być akceptowane przez innych uczestników rynku, a także zmian będących w sprzeczności z przyjętymi normami. Według Fullerton i Punj [1998] takie zachowania to wielki paradoks współczesnej kultury konsumpcyjnej. Dysfunkcyjne zachowania konsumentów stały się nieodłącznym elementem współczesnych zachowań konsumpcyjnych. Celem artykułu jest przegląd wyników badań dotyczących dysfunkcyjnych zachowań klientów na podstawie wybranych publikacji naukowych. Prezentacja kierunków i wyników badań będzie przedstawiona w dwóch odrębnych częściach. Pierwsza z nich dotyczy zachowań dysfunkcyjnych klientów tzn. sposobu ujmowania ich w literaturze przedmiotu oraz czynników determinujących takie zachowanie. Druga cześć zawiera przegląd wyników badań dotyczących szeroko rozumianych konsekwencji dysfunkcyjnych zachowań klientów.

Słowa kluczowe: zachowania klientów, dysfunkcyjne zachowania klientów, przegląd wyników badań 